\title{
THE VERIFICATION OF THE RSG-GAS REACTOR COOLING TOWER HEAT TRANSFER CAPACITY
}

\author{
Abdul Aziz Rohman Hakim', Nailul 'Atifah² \\ 1) Multipurpose Reactor Center, BATAN, South Tangerang, Indonesia, \\ hakim@batan.go.id \\ 2) Mechanical Engineering Study Program, UNPAM, South Tangerang, Indonesia, \\ ibunyayusuf@gmail.com
}

\begin{abstract}
ABSTRAK
VERIFIKASI KAPASITAS PEMINDAHAN PANAS MENARA PENDINGIN REAKTOR RSG-GAS. Telah dilakukan penggantian menara pendingin Reaktor RSG-GAS. Spesifikasi teknis menara pendingin baru menyebutkan kemampuan pemindahan panas dari air pendingin sekunder ke lingkungan sebesar $5500 \mathrm{~kW}$ per modul. Penelitian ini menguraikan tentang verifikasi kemampuan pemindahan panas dari pendingin sekunder ke lingkungan dengan perhitungan teoritis menggunakan data hasil pengujian. Pada operasi daya 30 MW yang dilakukan pada 20 Desember 2018, dilakukan pengambilan data meliputi temperatur pendingin primer masuk dan keluar teras, temperatur pendingin sekunder masuk dan keluar menara pendingin, temperatur wet bulb dan temperatur dry bulb lingkungan, serta temperatur udara masuk dan keluar menara pendingin. Data tersebut digunakan untuk perhitungan kemampuan pemindahan panas dari air pendingin sekunder ke lingkungan. Dari perhitungan diperoleh bahwa setiap sel menara pendingin Reaktor RSG-GAS mampu memindahkan panas ke lingkungan sebesar 5528,52 kWatt. Nilai tersebut telah sesuai dengan spesifikasi teknis yang tertulis dalam Laporan Analisis Keselamatan RSG-GAS revisi 11.
\end{abstract}

Kata kunci: kapasitas, menara pendingin, panas, spesifikasi, teoritis

\begin{abstract}
The RSG-GAS reactor has been replaced and the technical specifications for the new cooling tower specify that the heat transfer capacity from the secondary cooling water to the environment is $5500 \mathrm{~kW}$ per module. Therefore, this study aims to verify the theoretical calculations of the heat transfer capacity using performance test data collected on the $30 \mathrm{MW}$ power operation on December 20, 2018, such as the temperature of the primary and secondary coolant entering and exiting the cooling tower, wet bulb and environmental dry bulb temperature, as well as the inlet and outlet air temperature. Furthermore, the data were used to calculate the heat transfer capacity from the secondary cooling water to the environment. The results showed that each cell of the RSG-GAS cooling tower reactor transfers the heat of approximately $5528.52 \mathrm{~kW}$. This value is consistent with the technical specifications written in the revised RSG-GAS Safety Analysis Report 11.
\end{abstract}

Keywords: capacity, cooling tower, heat, specification, theoretical.

\section{INTRODUCTION}

The Multipurpose G. A. Siwabessy (RSG-GAS) is a reactor used for research, irradiation, education, and training. The facility has been under construction since 1983, while the operation reached its first critical condition in July 1987. Besides, the reactor was inaugurated by the President of Indonesia on 20
August 1987 and the nominal power operation of $30 \mathrm{MW}$ was achieved in March 1992 [1].

The operating support system includes ventilation, process 1 and 2 , liquid waste collection, electrical, radiation, as well as earthquake monitoring, control rod drive, and reactor protection systems. Meanwhile, one component of process system 2 is the cooling tower [1]. Since commissioning, the cooling tower has been used for more than 30 years. This led to a decrease in the heat transfer 
capacity to the environment. Furthermore, a test on the cooling tower carried out in terrace 96 on 18 May 2018 showed that at 30 MW of operation for 45 minutes, the primary coolant reached a temperature of $41,962{ }^{\circ} \mathrm{C}$. The increasing trend of the primary coolant temperature tends to continue until a steady condition is reached. The reactor automatically SCRAM when used for a long time because the temperature of the primary coolant has exceeded the activation limit of the protection system which is $42^{\circ} \mathrm{C}$. Consequently, the RSGGAS cooling tower after 30 years of operation no longer meets the safety criteria for reactor operation [2].

The seven cell cooling towers of the RSG-GAS reactor have been replaced, while the heat transfer capacity to the environment was tested on December 20, 2018. The results showed that at a steady state of $30 \mathrm{MW}$, the temperature of the primary coolant leaving and entering the core is $44^{\circ} \mathrm{C}$ and $36^{\circ} \mathrm{C}$, while the inlet and outlet temperatures of the secondary coolant is $36.94^{\circ} \mathrm{C}$ and $29.86^{\circ} \mathrm{C}$ respectively. Additionally, 6 operating cooling towers were able to transfer heat to the environment. Furthermore, the temperature of the primary coolant entering the core did not exceed the activation limit of the protection system [3]. The project handover document stated that the cooling tower's heat transfer capacity is $\mathbf{5 5 0 0}$ $\mathrm{kW}$ per module. Therefore, this study aims to verify the cooling tower heat transfer capacity per module based on theoretical calculations using performance data.

\section{METHOD}

\section{Heat Transfer in Cooling Towers}

The cooling tower transfers heat from the water to the ambient air [4]. This process occurs due to direct contact in two ways, namely heat transfer from cooling water to air (sensible) and through evaporation (latent) [5]. Heat transfer from cooling water to air depends on the temperature and moisture content indicated by the Wet Bulb Temperature (WBT) parameter. Ideally, the cooling water might condense to WBT, but this has never been achieved given that the cooling water rarely has direct contact entirely with the air. Meanwhile, the Cold Water Temperature (CWT) depends on the contact time with the air and cooling water, the amount of surface area of the fill, and water that becomes droplets [6]. The smaller the difference between WBT and CWT, the better the cooling tower's heat transfer performance.

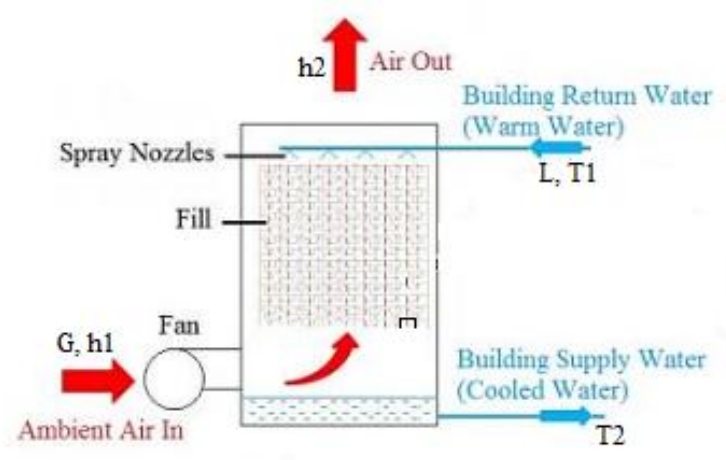

Figure 1. Cooling Tower Schematic [7]

Secondary cooling water with mass rate $\mathrm{L}$ and inlet temperature $\mathrm{T} 1$ enters and exits with outlet $\mathrm{T} 2$, while the environmental air with mass rate $G$ and enthalpy $h 1$ enters and exits with enthalpy h2. Heat transfer occurs from water to air and the cooling tower schematic is shown in Figure 1.

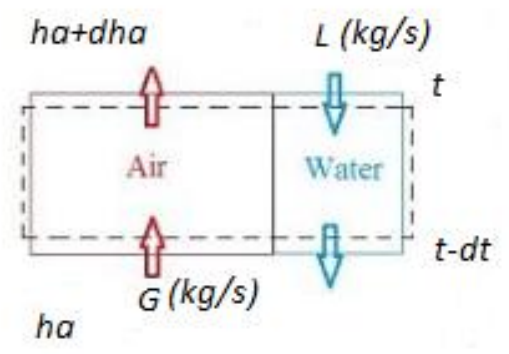

Figure 2. Control of Heat and Mass Transfer Volume in Cooling Tower [7, 8]

Figure 2 shows the volume control of the heat and mass transfer processes in a cooling tower. The analysis of heat and mass transfer is as follows. Water enters at $t$ and leaves the section at a lower temperature, i.e. t-dt, while air enters with ha and leaves with the enthalpy ha+dha. The rate of heat transfer from water is equal to the rate of heat received by air [9]. The equation is as follows [10]:

$$
d Q=G \cdot d h a=L \cdot C p \cdot d t
$$

According to the principle of enthalpy potential, the heat transferred from the cooling water to the air over a wide interval is: 


$$
d Q=\frac{h c \cdot d A}{C p m}(h i-h a)
$$

To calculate the heat transfer rate in all parts of the cooling tower, equations 1 and 2 are integrated to obtain the following equations:

$$
\begin{aligned}
& \text { L.Cp } \cdot \int_{\text {tout }}^{\text {tin }} \frac{d T}{h i-h a}=\int_{0}^{A} \frac{h c \cdot d A}{C p m} \\
& L . C p \cdot \int_{\text {tout }}^{\text {tin }} \frac{d T}{h i-h a}=\frac{h c \cdot A}{C p m} \\
& N T U=\frac{h c \cdot A / C p m}{G} \\
& Q=\frac{h c \cdot A}{C p m} \cdot(h i-h a)
\end{aligned}
$$

where:

$\mathrm{dq} \quad$ : heat transfer rate

$\mathrm{G}$ : air mass flow rate

dha : enthalpy change of air

$\mathrm{L} \quad$ : water mass rate

$\mathrm{Cp} \quad$ : the specific heat capacity of water

Dt : change in water temperature

hc : convection coefficient

hi :enthalpy of saturated air at the water temperature

ha : enthalpy of air

Cpm : humid air type heat

tin : inlet water temperature

tout : outlet water temperature

A : Heat Transfer Area

NTU : Number of Transfer Unit

The use of equations 1-6 is based on the assumption that the flow rates of water and air are constant.

Figure 3 shows the relationship between water and air and the driving potential of a counterflow cooling tower. $\mathrm{AB}$ is the line of work for water and is determined by the inlet and the cooling tower outlet temperature, while $\mathrm{CD}$ is the line for aerial work and starts from point $\mathrm{C}$ which indicates the enthalpy of air WBT. Furthermore, BC is the beginning of the enthalpy driving force, while the ratio of liquid to gas, $\mathrm{L} / \mathrm{G}$, is the line of action gradient. The air exits the cooling tower at point $\mathrm{D}$, while the cooling range is the projection of the $\mathrm{CD}$ line to the temperature scale or the difference between the cooling tower inlet and outlet water temperature. Meanwhile, the approach is the difference between the outlet temperature and the WBT of the ambient air. The cooling tower characteristic, $\mathrm{KaV} / \mathrm{L}$, is an integral value which indicates the area of $\mathrm{ABCD}$ and depends on the $\mathrm{L} / \mathrm{G}$ ratio [11].

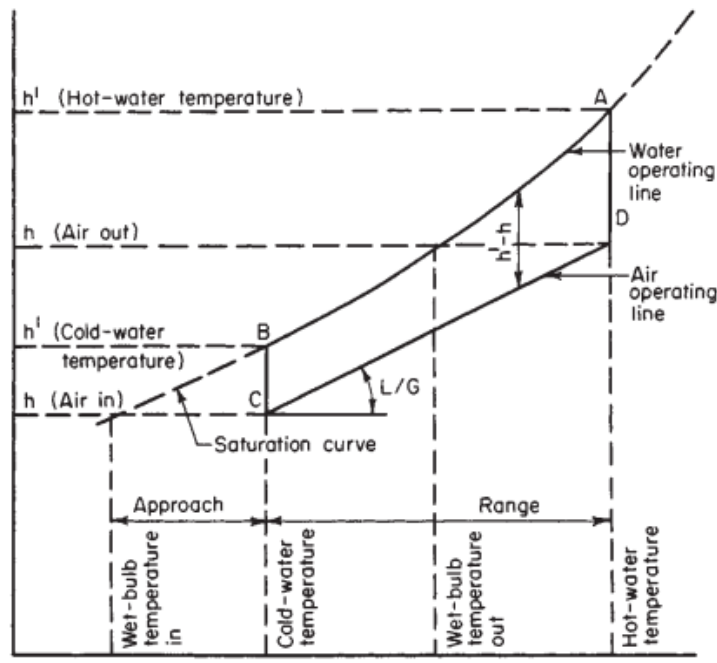

Figure 3. Water and Air Process Diagram [6]

\section{Verification Method}

The data used for the calculations are records of reactor operations and the results of cooling tower tests conducted by HAMON Company on December 20, 2018 [12, 13]. These include:

1. Coolant flow rate entering the cooling tower

2. Air flow rate in cooling tower

3. Temperature of secondary coolant entering the cooling tower

4. Secondary cooling temperature out of the cooling tower

5. Dry bulb temperature

6. Wet bulb temperature

7. Cooling tower intake air temperature

8. Cooling tower exit air temperature

The verification steps include:

1. Calculating the mass velocity of air and water

2. Dividing the heat transfer area into 5 parts

3. Calculating the energy balance at the bottom of the cooling tower (where the air enters)

4. Calculating the average enthalpy of air

5. Calculating the enthalpy of saturated air

6. Calculating the value of hc.A/Cpm (cooling tower characteristics)

7. Calculating the heat transfer capacity of cooling towers 


\section{RESULT AND DISCUSSION}

A thermal performance test was carried out on the cooling tower of the RSG-GAS Reactor on December 20, 2018, and the results are shown in Table 1.

Table 1. Summary of Cooling Tower Thermal Performance Test Results [12]

\begin{tabular}{llll}
\hline \multicolumn{1}{c}{ Parameter } & \multicolumn{1}{c}{ Unit } & \multicolumn{1}{c}{ Design } & \multicolumn{1}{c}{ Test } \\
\hline Inlet water & ${ }^{\circ} \mathrm{C}$ & 39,2 & 36,90 \\
\hline Outlet water & ${ }^{\circ} \mathrm{C}$ & 32,00 & 29,92 \\
\hline Range & $\mathrm{K}$ & 7,20 & 6,98 \\
\hline Dry bulb & ${ }^{\circ} \mathrm{C}$ & 30,96 & 32,00 \\
\hline Wet bulb & ${ }^{\circ} \mathrm{C}$ & 28,00 & 25,10 \\
\hline $\begin{array}{l}\text { Atmospheric } \\
\text { pressure }\end{array}$ & $\mathrm{mbar}$ & 1013 & 1013,00 \\
\hline Outlet air density & $\mathrm{Kg} / \mathrm{m}^{3}$ & 1,115 & 1,124 \\
\hline Air speed & $\mathrm{m} / \mathrm{s}$ & 4,5 & 2,9 \\
\hline Water flow rate & $\mathrm{m}^{3} / \mathrm{hour}^{2}$ & 3909 & 4148,00 \\
\hline Tower Capacity & $\%$ & & 107,1 \\
\hline
\end{tabular}

The test carried out during operation with a power of $30 \mathrm{MW}$ shows that the cooling tower transfers heat to the environment hence, the temperature of the primary coolant entering the core is at a steady-state of $36^{\circ} \mathrm{C}$. This value is still far from the limit for the activation of the reactor protection system, which is $42^{\circ} \mathrm{C}$. This situation shows that the replacement of the cooling tower has been able to meet the safety aspects of reactor operation.

The data used for the calculations are shown in Appendix 1 of Table 2. The first calculation performed was the mass rate of water and air entering the cooling tower and the results showed that the values were $179.98 \mathrm{~kg} / \mathrm{s}$ and $115.28 \mathrm{~kg} / \mathrm{s}$ respectively. Hence, the ratio of cooling water and air rate, $\mathrm{L} / \mathrm{G}$ was 1.56 . This value is the slope of the working air line passing through the cooling tower. The calculations for water and air mass rates are shown in Appendix 1 Table 3.

The heat transferred to the environment was determined by calculating the characteristics of the cooling tower using equation (4). This was carried out by dividing the cooling tower temperature area into 5 parts hence, the $\mathrm{dT} / \mathrm{n}$ value is $1.396^{\circ} \mathrm{C}$. The energy balance at the bottom of the cooling tower was then calculated and obtained a value of 9.13 $\mathrm{kJ} / \mathrm{kg}$. The next step was to calculate the value of hc.A/Cpm as shown in Appendix 1 of Tables 4 to 6 . The calculations obtained a value of $219.3098 \mathrm{~kg} / \mathrm{s}$ which was then used to determine the characteristics of the cooling tower including the performance on inlet water temperature and WBT.

The NTU value was calculated using equation (5) and the results obtained a value of 1.9 which indicates the characteristics of the cooling tower, or in Merkel Theory referred to as the Merkel Number [6]. A large NTU value indicates that the outlet temperature is closer to the WBT of the inlet air and also a smaller approach. Meanwhile, the closer the approach value to WBT, the better the condition of the cooling tower. This value depends on the contact time between water and air, the surface area of the fill, and the amount of water that becomes a droplet.

After obtaining the hc.A/Cpm value, the heat transfer capacity to the environment was then calculated using Equation (6). The $\mathrm{Q}$ value which represents heat transferability is indicated by the inlet air or the water falling into the cooling tower pool, namely Q1. The calculation of the heat transfer capacity is shown in Appendix 1 of Table 7. A Q value of 5528.52 $\mathrm{kW}$ was obtained based on the theoretical calculations from the cooling tower test results at a nominal power of $30 \mathrm{MW}$.

\section{CONCLUSION}

The heat transfer capacity of the cooling tower to the environment is $5528.52 \mathrm{~kW}$ per module. This value is consistent with the specifications and contract requirements for the RSG-GAS cooling tower revitalization and cooling tower design data in the Revised 11 LAK.

\section{REFERENCES}

1 PRSG-BATAN, "Laporan Analisis Keselamatan Rev. 11," Dokumen Keselamatan Operasi Reaktor, vol. 1, pp. I-1, - 2018.

2 Abdul Aziz R.H., "Tinjauan Keselamatan Operasi Reaktor Terhadap Kinerja Menara Pendingin Setelah 30 Tahun Beroperasi," Reaaktor Buletin Pengelolaan Reaktor Nuklir, vol. XVI, No. 1, pp. 1-21, 2019.

3 Abdul Aziz R.H., "Tinjauan Keselamatan Operasi Reaktor Serba Guna G. A. Siwabessy Setelah Penggantian Menara Pendingin," Reaaktor Buletin 
Pengelolaan Reaktor Nuklir, vol. XVII, No. 1, pp. 27-37, 2020.

4 S. Fisenko, A. Brin, and A. Petruchik, "Evaporative cooling of water in a mechanical draft cooling tower," International Journal of Heat and Mass Transfer, vol. 47, pp. 165-177, 2004.

5 S. Fisenko and A. Brin, "Simulation of a cross-flow cooling tower performance," International Journal of Heat and Mass Transfer, vol. 50, pp. 3216-3223, 2007.

6 R. H. Perry, "Perry's Chemical Engineers' Handbook," vol. Seventh pp. 12-14, 1997.

7 M. Nasrabadi, D. Finn, and B. Costelloe, "Mathematical Modelling of a Low Approach Evaporative Cooling Process for Space Cooling in Buildings," in 10th IIR Gustav Lorentzen Conference, June 25-27 2012, Delft, The Netherlands, 2012.

8 Abdul Aziz R.H., "Analysis of Heat and Mass Transfer on Cooling Tower Fill," Jurnal Forum Nuklir, vol. 14 No 1, pp. 2530, 2020.

9 H. A. S. Donald R. Baker, "A Comprehensive Approach to the Analysis of Cooling Tower Performance," SPX Corporation, vol. TB-R61P13, 2016.

10 D. Q. Kern, "Process Heat Transfer," Book, 1983.

11 P. L. Couture, "Thermal-Hydraulic Design of Replacement Cooling Towers for Vermont Yankee Nuclear Power Station," Thesis, vol. -, 2010.

12 P. HAMON, "COOLING TOWER BATAN (PRSG)," Dokumen Serah Terima, vol. -, pp. -, - 2018.

13 PRSG-BATAN, "Lembar Data Operasi Reaktor," Dokumen Operasi Reaktor, 2018. 
Appendix 1.

Table 2. The Calculation Data

\begin{tabular}{lrll}
\hline Data & Value & Unit & Description \\
\hline Water flow rate & 651,44 & $\mathrm{~m} 3 / \mathrm{h}$ & Design \\
\hline Air flow rate & 104,8 & $\mathrm{~m} 3 / \mathrm{s}$ & Design \\
\hline Inlet water to the cooling tower & 36,90 & ${ }^{\circ} \mathrm{C}$ & Measurement \\
\hline Outlet water of cooling tower & 29,92 & ${ }^{\circ} \mathrm{C}$ & Measurement \\
\hline Dry Bulb Temperature & 32,00 & ${ }^{\circ} \mathrm{C}$ & Measurement \\
\hline Wet Bulb Temperature & 25,10 & ${ }^{\circ} \mathrm{C}$ & Measurement \\
\hline Tb1 (inlet air) & 32,00 & ${ }^{\circ} \mathrm{C}$ & Measurement \\
\hline Tb2 (outlet air) & 38,00 & ${ }^{\circ} \mathrm{C}$ & Measurement \\
\hline
\end{tabular}

Table 3. The Calculation of Water Mass Rate and Air Mass Rate

\begin{tabular}{|c|c|c|}
\hline Data & Value & Unit \\
\hline Range & 6,98 & ${ }^{\circ} \mathrm{C}$ \\
\hline Approach & 4,82 & ${ }^{\circ} \mathrm{C}$ \\
\hline T water average & 33,42 & ${ }^{\circ} \mathrm{C}$ \\
\hline $\mathrm{P}$ water at $\mathrm{T}$ mean & 994,62 & $\mathrm{~kg} / \mathrm{m} 3$ \\
\hline $\mathrm{L}$ (water flow rate $\mathrm{x} \rho$ water) & 647933,10 & $\mathrm{~kg} / \mathrm{h}$ \\
\hline $\mathrm{L}$ & 179,98 & $\mathrm{~kg} / \mathrm{s}$ \\
\hline $\mathrm{T}$ air average & 35,00 & ${ }^{\circ} \mathrm{C}$ \\
\hline$\rho$ air at $T$ mean & 1,11 & $\mathrm{~kg} / \mathrm{m} 3$ \\
\hline $\mathrm{G}$ (flow rate $\mathrm{x} \rho$ air) & 6916,8 & $\mathrm{~kg} / \mathrm{m}$ \\
\hline G & 115,28 & $\mathrm{~kg} / \mathrm{s}$ \\
\hline L/G & 1,56 & \\
\hline Cooling Tower divided by $5, \mathrm{dT} / \mathrm{n}$ & 1,396 & ${ }^{\circ} \mathrm{C}$ \\
\hline \multicolumn{3}{|c|}{ The bottom of the energy balance, $d($ ha, $n-h a, n-1)=h a, 1-h a, 0$} \\
\hline ha, $1-h a, 0=L / G \times 4,19 \times$ dT/n & 9,13 & $\mathrm{~kJ} / \mathrm{kg}$ \\
\hline
\end{tabular}

Table 4. The Calculation of Mean Value of Air Enthalpy

\begin{tabular}{lrrr}
\hline ha,n=ha,n-1+L/G x 4,19 x dT/n & Value & Unit & ha, mean \\
\hline ha,0=ha(TWB, TDB)=h inlet air & 76,29 & $\mathrm{~kJ} / \mathrm{kg}$ & \\
\hline ha,1=ha,0+L/G x 4,19 x dT/n & 85,42 & $\mathrm{~kJ} / \mathrm{kg}$ & 80,86 \\
\hline ha,2=ha,1+L/G x 4,19 x dT/n & 94,55 & $\mathrm{~kJ} / \mathrm{kg}$ & 89,99 \\
\hline ha,3=ha,2+L/G x 4,19 x dT/n & 103,69 & $\mathrm{~kJ} / \mathrm{kg}$ & 99,12 \\
\hline ha,4=ha,3+L/G x 4,19 x dT/n & 112,82 & $\mathrm{~kJ} / \mathrm{kg}$ & 108,25 \\
\hline ha,5=ha,4+L/G x 4,19 x dT/n & 121,95 & $\mathrm{~kJ} / \mathrm{kg}$ & 117,38 \\
\hline
\end{tabular}

Table 5. The Calculation of Enthalpy of Saturated Air

\begin{tabular}{lllllll}
\hline \multicolumn{2}{c}{ T water $\left({ }^{\circ} \mathrm{C}\right)$} & T mean $\left({ }^{\circ} \mathrm{C}\right)$ & In Pws & Pws & Ws & hi, mean \\
\hline T0 & 29,92 & & & & & \\
\hline T1 & 31,32 & 30,62 & 8,43 & 4577,53 & 0,02943 & 106,06 \\
\hline T2 & 32,71 & 32,01 & 8,51 & 4953,52 & 0,03197 & 114,05 \\
\hline T3 & 34,11 & 33,41 & 8,59 & 5356,04 & 0,03471 & 122,57 \\
\hline T4 & 35,50 & 34,81 & 8,66 & 5786,60 & 0,03767 & 131,65 \\
\hline T5 & 36,90 & 36,20 & 8,74 & 6246,84 & 0,04087 & 141,36 \\
\hline
\end{tabular}

Table 6. The Calculation of hc.A/Cpm

\begin{tabular}{lrr}
\hline hi-ha & $(\mathrm{kJ} / \mathrm{kg})$ & $1 /$ (hi-ha) \\
\hline h1-ha,1 & 25,21 & 0,0397 \\
\hline h2-ha,2 & 24,06 & 0,0416 \\
\hline h3-ha,3 & 23,45 & 0,0426 \\
\hline h4-ha,4 & 23,40 & 0,0427 \\
\hline h5-ha,5 & 23,97 & 0,0417 \\
\hline Total & 0,2083 \\
\hline hc.A/Cpm = Lx 4,19 x dT x 2 1/(hi-ha) & \\
\hline hc.A/Cpm (kg.d.a/kJ) & 219,3098 \\
\hline
\end{tabular}


Jurnal Forum Nuklir Volume 15, Nomor 1, Mei 2021

Table 7. The Calculation of Heat Transfer Capacity

\begin{tabular}{lrl}
\hline $\mathrm{Q}=$ hc.A/Cpm.(hi,n-ha,n) & Value & Unit \\
\hline $\mathrm{Q} 1=$ hc.A/Cpm.(hi,1-ha,1) & 5528,524 & $\mathrm{~kW}$ \\
\hline $\mathrm{Q} 2=$ hc.A/Cpm.(hi,2-ha,2) & 5277,460 & $\mathrm{~kW}$ \\
\hline $\mathrm{Q} 3=$ hc.A/Cpm.(hi,3-ha,3) & 5142,384 & $\mathrm{~kW}$ \\
\hline $\mathrm{Q} 4=$ hc.A/Cpm.(hi,4-ha,4) & 5132,333 & $\mathrm{~kW}$ \\
\hline Q5= hc.A/Cpm.(hi,5-ha,5) & 5257,116 & $\mathrm{~kW}$ \\
\hline
\end{tabular}


